Ethiopian Journal of Environmental Studies \& Management 10(5): 642 - 653, 2017.

ISSN:1998-0507

doi: https://dx.doi.org/10.4314/ejesm.v10i5.8

Submitted: March 20, 2017

Accepted: June 30, 2017

\title{
DETERMINING FACTORS FOR HOUSING AFFORDABILITY IN IBADAN, NIGERIA
}

\section{BABATUNDE FEMI AKINYODE}

Department of Urban and Regional Planning, Faculty of Environmental Sciences, Ladoke Akintola University of Technology, P.M.4000, Ogbomoso, Oyo state, Nigeria

Email: femladakinyode@yahoo.co.uk

\begin{abstract}
Housing affordability has been a concern in developed and developing world because of its role in man's welfare and productivity. This study aims at investigating determining factors for housing affordability in Ibadan urban centres. Questionnaire was developed based on consumers' evaluation on variables identified from the literatures. The administration of questionnaire was carried out among 494 respondents within five local government areas that constitute Ibadan metropolis. The data collected was analysed statistically using statistical softwares SPSS version 22. Exploratory Factor Analysis (EFA) technique was applied to define the determining factors for housing affordability. The result through EFA revealed house rents, housing preference, housing satisfaction, land price and government intervention as the determining factors for housing affordability. The multiple regression analysis confirmed land price, housing satisfaction and housing preference to be the most significant factors. The study encouraged and suggested urgent steps to be taken for the improvement and transformation in the Nigerian housing delivery to achieve affordable housing in Ibadan urban centres.
\end{abstract}

Key Words: Determining factor, Housing, Housing affordability, Ibadan, Urban centres

\section{Introduction}

Housing is one of the best indicators of a person's standard of living and his or her position in the society (Ademiluyi, 2010; Nubi, 2008). Tsai and Pen (2011) saw it as extremely important and unique asset for most people while house price and household income were seen as the most important determinants of homeownership affordability (Chen, et al., 2007; Tsai and Pen, 2011). Household desire to live in an urban centre is increasing at an alarming rate. Opportunity for employment, urban amenities and utilities consumption have been attributed to an increasing household desires and taste to live in an urban centre. This has ensued to increase in housing demand in Nigerian urban centres with particular reference to Ibadan.

This consequently brought in problem of housing affordability to low-income households. There is therefore need for the development of a strategy through which housing affordability would be met by different consumers irrespective of their socio-economic status. There is 
need to facilitate housing units' provision in sufficient quantity with a reasonable cost. These cannot be achieved without thorough understanding of the determining factors for housing affordability. This study aims at investigating determining factors for housing affordability in Ibadan urban centres. This is with a view of meeting consumers' needs, aspirations and priorities. The rest of the paper is arranged in the following order: section two focuses on the literature review followed by the discussion of the methodology adopted to achieve the aim of the study. The section four highlights the results and discussions while section five gives the policy implication and recommendations before the conclusion in section six.

\section{Literature Review}

Affordable housing has become a serious and considerable challenge especially for low incomes households which resulted from continue growth and expansion of the urban centre. The determinants of housing affordability include household income and house price (Olatubara, 2007). Housing affordability is the capacity of household or individual to meet housing costs while maintaining the ability to meet other basic costs of living without any problem. This explains the extent to which the household or individuals are able to pay for housing. CIH (1992) as quoted in Onu and Onu (2012) identifies variables which determine whether accommodation is affordable or not. These variables include rent levels, household income and eligibility of households for housing benefits where practised. House rent represents the level of payment that is required to secure housing unit (Bramley, 2011). The housing industry is composed of competitive firms. The industry's aggregate supply depends on its output price and the real price of housing structure. Limits to supply of any factor of construction and increases in demand for construction will boost the equilibrium price of houses (Lee and Ong, 2005). This is supported by Meen (2002) who asserted that positive demand in housing leads to a temporary increase in house rents on the short-run when there is inelastic housing supply, but rents overshoot on the long run. Declining in the household consumption, employment and overall economic growth in New Zealand resulted to reduction in housing construction which at long run affected the house rent to be increased (Snively, 2009). Net migration flows that generate more housing demand when the housing stock is in short supply result to changes in house rents. The increase in demand increases house rent. However, house rent fluctuations in housing market pose a greater risk to renters (Sinai and Souleles, 2003) which might push them to neighbourhoods with lower rents and lower expected appreciation. Akinyode (2014) discovered in his study that the materials and technology used for the housing construction may not satisfy the consumers but it has influence on house rent and affordability.

Preference is regarded as valueoriented and goal-directed activities (Coolen et al., 2002). The locational attributes of housing such as distance and convenient to workplace, amenities like schools, retailing outlets and public transportation stations (Clark et al., 2006; 
Tan, 2012; Wang and $\mathrm{Li}, 2006)$ were found to be imperative factors that determine housing preference (Kauko, 2007). According to Tan (2012), households prefer and have the willingness to pay more for a house that is located in a good neighbourhood with good environmental qualities and in neighbourhoods with low crime rates and other security problems (Wang and $\mathrm{Li}$, 2006). Anticipation of the improvement of a particular neighbourhood may be the determining factor why household decides to move to another neighbourhood (Ellen et al., 2013). Collen and Hoekstra (2001) opined that values played significant role in consumers' behaviour towards their housing preferences. Location of the neighbourhood itself drives household to another neighbourhood as a result of value being attached to such neighbourhood. Cost of land, bureaucratic challenges related to land acquisition and high interest rate constituted problems to affordable supply of rental housing (Arku et al., 2012; Gough and Yankson, 2011). Arimah (1997) affirmed access to land and household size as other determining factors to housing affordability.

Upon various studies on housing affordability, the systematic conceptualisation and empirical investigation of consumers' evaluation on housing affordability was yet to be done. The present study extends the literature by identifying and testing the determining factor for housing affordability through consumers' evaluation.

\section{Methodology}

This study made use of quantitative research methods through the administration of questionnaire among 113 respondents in Ibadan North, 119 respondents in North-East, 59 respondents in North-West, 101 respondents in South-East and 108 respondents in South-West totaled 500 respondents. The questionnaire was developed based on consumers' evaluation on their present affordable house and designed in the Likert scale format. The respondents were requested to choose between strongly disagreed given 1 point and strongly agree given 5 points. This allowed respondents to indicate the level of agreement with the constructed statements relating to the evaluation of their present house.

After verification of the questionnaires, 494 questionnaires representing $98.80 \%$ response rate of the total sampled size were found useful for the analysis. This indicates that the study suffers from a nonresponse bias of $01.20 \%$. This is considered to be good response rate within the recommendation of Jack (2008). Stratified sampling was adopted for data collection and analysed statistically using statistical softwares SPSS version 22. Cronbach's alpha value result of 0.66 used to access the internal consistent reliability of the survey instrument was considered sufficiently reliable for an exploratory study like this (Hair et al., 2010; Newton and Meyer, 2010; Shanmugapriya and Subramanian, 2013; Wong and Cheung, 2005).

The study also recorded higher respondents of 494 administered questionnaires with KMO value of 0.864 that signifies reliable, adequate and valid survey sampling (Field, 2009). The use of 
Determining Factors for Housing Affordability in Ibadan................AKINYODE, B.F.

maximum likelihood parameter estimation with listwise deletion of missing cases was applied. Exploratory factor analysis (EFA) through SPSS software was used because of its effectiveness in reducing data in behavioural and social sciences research in order to achieve the objectives.

Regression analysis was employed to ascertain the significant predictors of housing affordability. Multiple regression was performed on determining factors extracted from EFA to appraise the significance level of determining factors. The interpretation and explanation were made through qualitative judgement.

\section{Results and Discussions}

\section{Exploratory Factors Analysis (EFA)}

Barlett's test of sphericity having significance at 0.000 indicates that the correlation matrix is not an identity matrix. Kaiser-Meyer-Olk in measure of sampling adequacy is also sufficient with the value of 0.864 . These two parameters justified the suitability and applicability of the EFA on the item variables thereby leading to the employment of principal component analysis technique. EFA was performed on all the item variables to examine their loadings and five factors were extracted using latent root criterion (with eigen values greater than 1). Statistics of initial variance explained and after rotation are shown in the Table 1. With five extracted factors, $64.28 \%$ of variance is accounted for housing affordability.

Table 2 shows five factor loadings extracted from factor analysis technique to confirm the determining factors in this study. Item attributes that manifested equal or greater than 0.5 coefficient in the factor constructs were considered significant as determining factors. In achieving this, the item variables with any factor loading that is less than raw scaled value 0.4 and rescaled value 0.5 in rotated matrix was excluded as part of the determining factors. The remaining 21 items were then grouped into five factors identified as the determining factors that influence housing affordability. 
Table 1: Total variance explained

\begin{tabular}{|c|c|c|c|c|c|c|c|c|c|c|}
\hline & \multirow[b]{2}{*}{ Component } & \multicolumn{3}{|c|}{ Initial Eigenvalues } & \multicolumn{3}{|c|}{$\begin{array}{c}\text { Extraction Sums of Squared } \\
\text { Loadings }\end{array}$} & \multicolumn{3}{|c|}{$\begin{array}{c}\text { Rotation Sums of Squared } \\
\text { Loadings }\end{array}$} \\
\hline & & Total & $\begin{array}{c}\% \text { of } \\
\text { Variance }\end{array}$ & $\begin{array}{c}\text { Cumulative } \\
\%\end{array}$ & Total & $\begin{array}{c}\% \text { of } \\
\text { Variance }\end{array}$ & $\begin{array}{c}\text { Cumulative } \\
\%\end{array}$ & Total & $\begin{array}{c}\% \text { of } \\
\text { Variance }\end{array}$ & $\begin{array}{c}\text { Cumulative } \\
\%\end{array}$ \\
\hline \multirow[t]{5}{*}{ Raw } & 1 & 2.314 & 5.868 & 50.618 & 2.314 & 5.868 & 50.618 & 3.533 & 8.958 & 43.326 \\
\hline & 2 & 1.753 & 4.446 & 55.064 & 1.753 & 4.446 & 55.064 & 1.981 & 5.022 & 48.348 \\
\hline & 3 & 1.600 & 4.057 & 59.121 & 1.600 & 4.057 & 59.121 & 2.541 & 6.443 & 54.791 \\
\hline & 4 & 1.321 & 3.350 & 62.470 & 1.321 & 3.350 & 62.470 & 1.947 & 4.936 & 59.728 \\
\hline & 5 & 1.158 & 2.937 & 65.408 & 1.158 & 2.937 & 65.408 & 1.797 & 4.557 & 64.284 \\
\hline \multirow[t]{5}{*}{ Rescaled } & 1 & 2.314 & 5.868 & 50.618 & 2.184 & 5.199 & 44.777 & 2.576 & 6.135 & 37.924 \\
\hline & 2 & 1.753 & 4.446 & 55.064 & 1.418 & 3.375 & 48.152 & 2.503 & 5.960 & 43.884 \\
\hline & 3 & 1.600 & 4.057 & 59.121 & 1.503 & 3.580 & 51.732 & 2.249 & 5.356 & 49.240 \\
\hline & 4 & 1.321 & 3.350 & 62.470 & 1.481 & 3.525 & 55.257 & 2.182 & 5.195 & 54.436 \\
\hline & 5 & 1.158 & 2.937 & 65.408 & 1.429 & 3.402 & 58.659 & 1.537 & 3.659 & 58.094 \\
\hline
\end{tabular}


Table 2: Exploratory factor analysis (EFA) loading results

\begin{tabular}{|c|c|c|c|c|c|c|c|c|c|c|}
\hline \multicolumn{11}{|c|}{ Rotated Component Matrix } \\
\hline \multirow[t]{2}{*}{ VARIABLES } & \multicolumn{5}{|c|}{ Raw Component } & \multicolumn{5}{|c|}{ Rescaled Component } \\
\hline & $\mathrm{A}$ & $\mathrm{B}$ & $\mathrm{C}$ & $\mathrm{D}$ & $\mathrm{E}$ & A & $\mathrm{B}$ & $\mathrm{C}$ & $\mathrm{D}$ & $\mathrm{E}$ \\
\hline Landlords Decision & 1.135 & & & & & .827 & & & & \\
\hline High House Rent & .781 & & & & & .762 & & & & \\
\hline Short Housing Supply & .810 & & & & & .742 & & & & \\
\hline Income & .921 & & & & & .726 & & & & \\
\hline General Inflation & .974 & & & & & .726 & & & & \\
\hline House Rent Not Satisfied & .643 & & & & & .641 & & & & \\
\hline Good Physical Condition & & 631 & & & & & .734 & & & \\
\hline House Well Maintained & & .696 & & & & & .721 & & & \\
\hline High Income Earners & & .575 & & & & & .652 & & & \\
\hline People's Level of Education & & .516 & & & & & .623 & & & \\
\hline Area is Suitable & & .444 & & & & & .567 & & & \\
\hline Lack of Facilities & & & .771 & & & & & .743 & & \\
\hline House Environment & & & .667 & & & & & .742 & & \\
\hline House Security & & & .647 & & & & & .691 & & \\
\hline Work of Place Distance & & & .459 & & & & & .520 & & \\
\hline High Demand on Land & & & & .445 & & & & & .627 & \\
\hline Increase in Population & & & & .402 & & & & & .596 & \\
\hline Expensive Land Area & & & & .406 & & & & & .591 & \\
\hline $\begin{array}{l}\text { Government's impact on } \\
\text { Housing Typology }\end{array}$ & & & & & .940 & & & & & .877 \\
\hline $\begin{array}{l}\text { Government's impact on Rate } \\
\text { of Housing Supply }\end{array}$ & & & & & .925 & & & & & .860 \\
\hline $\begin{array}{l}\text { Government's impact on } \\
\text { Housing Suppliers' Decision }\end{array}$ & & & & & .746 & & & & & 677 \\
\hline
\end{tabular}

Extraction Method: Principal Component Analysis; Rotation Method: Varimax with Kaiser Normalization; a: Rotation converged in 25 iterations; Absolute value: loading less than 0.4

The five factors as shown in Table 2 with total number of 21 variables to measure them are named as House Rents consisting of six variables; Housing Preference with five variables; Housing Satisfaction with four variables; Land Price with three variables and Government Intervention with three variables.

Determining Factors that Influence Housing Affordability

The five factors are interpreted and explained through qualitative judgement as followed.

\section{House Rents}

This factor grouping named house rents accounts for $43.33 \%$ as shown in Table 1 of the total variances between principal factors. Landlord's decision, high house rents, shortage housing supply, income, general inflation and house rents not satisfied are the six variables that composed the house rents. House rent is highly associated with landlord's decision, shortage housing supply compared with demand and general inflation. Shortage of housing supply and high housing demand leads to high house rent and limits housing 
affordability to low and middle income consumers. Population increase through influx of migrants contributes to the increase in housing demand which cannot match the supply. This leads to many consumers competing for the limited available houses in the market. Low wages in terms of income and general inflation prevent majority of consumers from having their personal house thereby results to housing supply shortage. The problem of low income resulting to housing supply shortage will continually lead to increase in house rental price. Many households will continue to face difficulty in meeting quality and affordable housing except urgent steps are taken to improve and transform housing delivery. From the author's observation, house rents are not only determined by the aforementioned variables but also by location advantage. When the house is decided to be sold for commercial purpose, the location advantage takes a pre-eminence in house price.

\section{Housing Preference}

This factor grouping named housing preference accounts for $48.35 \%$ as shown in Table 1 of the total variances between principal factors. The factor comprises of good physical condition, well maintained, high income earners area, people's education and area suitable for living. These play a vital role in motivating some consumers in housing preference. The significant factors of housing preference for high income earners include attractive physical condition, residents' social status and their educational background within the neighbourhood as well as location suitability in terms of safety. Housing preference as a function of location, house type, construction materials, finishing and the facilities provided are relevant in housing affordability among high income consumers. This is in line with the investigation result of some other scholars (Collen and Hoekstra, 2001; Ellen et al., 2013; Tan, 2012; Wang and $\mathrm{Li}, 2006$ ) that opined that consumers attached more value to neighbourhood that is safe and secure.

\section{Housing Satisfaction}

This factor grouping named housing satisfaction accounts for $54.79 \%$ as shown in Table 1 of the total variances between principal factors. Housing satisfaction is a process of evaluating between what consumers received and their expectation. Based on EFA, consumers attached greater importance to four variables affecting their satisfaction. These include facilities, environment, security and distance to the place of work. Satisfaction with the distance between consumers' house and place of work results from the fact that, close distance between house and place of work reduces the financial burdens associated with commuting to and fro work every day. This support the result of Ibem and Amole (2013) in their study where consumers were satisfied with their housing unit due to the closeness of their house to place of their work.

\section{Land Price}

This factor grouping named land price accounts for $59.73 \%$ as shown in Table 1 of the total variances between principal factors. Land is one of the major factors of housing production. Land price indicates the market price that owners or agents place on a particular location. According to EFA performed, land price significantly influenced by high demand, increase in population and 
the area with the provision of infrastructural facilities. High demand on land results from increase in population through push and pull factors. This consequently leads to high land price and becomes significant factor for housing affordability problem in Ibadan urban centre.

\section{Government Intervention}

This factor grouping named government intervention accounts for $64.28 \%$ as shown in Table 1 of the total variances between principal factors. Government intervention is one of the determining factors that affects housing affordability. This comprises of three variables and these include government's impact on housing typology, on the rate of housing supply and on housing suppliers' decision as it relates to their income capability. Government's intervention in terms of planning regulation as a tool of development control, delay in obtaining house plan approval and the cost of processing fees at the zonal town planning authorities significantly contribute to housing production costs, affordability and weigh heavily on house ownership. Though government intervention in terms of planning regulation aims at improving consumers' living standard in terms of improving the environment but discourages some developers in housing supply.

Table 3: Model Summary ${ }^{\mathrm{b}}$
The next section discusses the result of multiple regression performed on determining factors extracted from exploratory factor analysis to appraise their significance level.

\section{Regression Analysis of the Principal Factors}

Multiple regression was conducted between housing affordability as the dependent variable and 5 underlying determining factors (House rent, housing preference, housing satisfaction, land price and government intervention) as independent variables, using "enter method". Table 3 of the model summary specifies coefficient of determination $\left(R^{2}\right)$ value of 0.158 indicating $16 \%$ of the variance in housing affordability was explained by the model. Adjusted R$\begin{array}{llll}\text { square value (adjusted } & \mathrm{R}^{2} \text { ) } & 0.149\end{array}$ representing approximately $15 \%$ of the housing affordability variance was explained by the three significant factors. Though, the $\mathrm{R}$ square value for the model is low, signifying that most of the variation in housing affordability was not explained by the predictor variables. However, this value is reliable and considered reasonably above an acceptable range of $15 \%$ postulated by Mitchell and Carson (1989) in page 213 of their book. This is acceptable in social sciences when cross-sectional data were used (Kotchen and Reiling, 2000; Wattage et al., 2000).

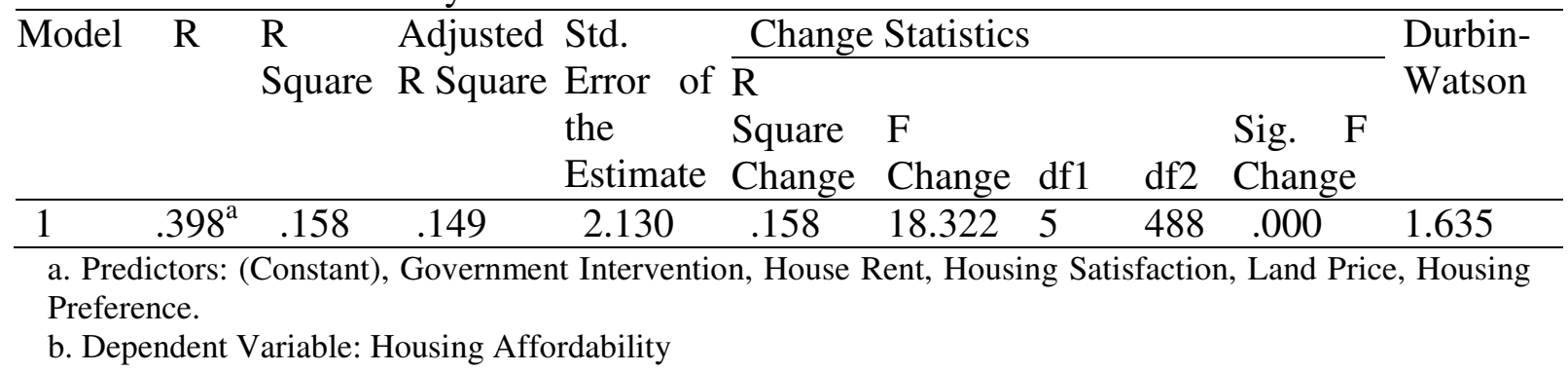


Besides, out of the five factors, only House Rent, Housing satisfaction and Land Price are significant at $\mathrm{p}<0.000$ while housing preference and government intervention are not significant as shown in Table 4. Among the three significant underlying determining factors, land price contributed considerably to the prediction of housing affordability (Standardized Coefficients $0.152, \mathrm{p}<0.000$ ) followed by housing satisfaction (Standardized Coefficients $0.175, \mathrm{p}<0.000$ ) and house rent (Standardized Coefficients 0.305, $\mathrm{p}<0.000$ ) of variance in overall housing affordability as shown in Table 4.

Table 4: Coefficients ${ }^{\mathrm{a}}$

\begin{tabular}{|c|c|c|c|c|c|c|c|}
\hline \multirow[b]{2}{*}{ Model } & \multicolumn{3}{|c|}{$\begin{array}{ll}\text { Unstandardized } & \text { Standardized } \\
\text { Coefficients } & \text { Coefficients } \\
\end{array}$} & \multirow[b]{2}{*}{$\mathrm{t}$} & \multirow[b]{2}{*}{ Sig. } & \multicolumn{2}{|c|}{$\begin{array}{l}95.0 \% \text { Confidence } \\
\text { Interval for B }\end{array}$} \\
\hline & B & $\begin{array}{l}\text { Std. } \\
\text { Error }\end{array}$ & Beta & & & $\begin{array}{l}\text { Lower } \\
\text { Bound }\end{array}$ & $\begin{array}{l}\text { Upper } \\
\text { Bound }\end{array}$ \\
\hline 1 (Constant) & 7.667 & 1.140 & & 6.726 & .000 & 5.427 & 9.906 \\
\hline House Rent & .149 & .021 & .305 & 7.061 & .000 & .107 & .190 \\
\hline House Preference & .007 & .055 & .006 & .125 & .901 & -.101 & .115 \\
\hline House not satisfied & -.146 & .040 & -.175 & -3.641 & .000 & -.225 & -.067 \\
\hline Land Price & .198 & .056 & .152 & 3.535 & .000 & .088 & .308 \\
\hline Government Intervention & .151 & .109 & .060 & 1.379 & .168 & -.064 & .365 \\
\hline
\end{tabular}

${ }^{\mathrm{a}}$ Dependent Variable: Housing Affordability

Five determining factors are found to influence housing affordability while three of them are significant. This informed the literature of the potential consumers' evaluation through which the public and private housing sectors can define the determining factors that influence housing affordability. Through this, affordable housing to different socio-economic status could be met. The next section therefore suggests several interesting ways through which effective housing affordability could be met.

\section{Policy Implication and Recommendation}

The policy, program and decision making in meeting consumers' housing affordability of different socio-economic status should be based upon realistic estimation and multi-dimensional nature of quantitative and qualitative affordable housing. This is to assist the consumers in living a better and decent environment that is safe, comfortable and convenience. In achieving this, the author is of opinion that proper attention should be given to the following recommendations:

\section{Housing policy and Counselling Programs}

The policy should provide housing search assistance to both prospective home owners and renters. The establishment of national housing policy and counselling programs should help households and individuals secure decent and affordable housing that are best fit their needs, regardless of whether the house is owned or rented.

\section{Government Assistance as Guarantor}

The government needs to arise and assist the Nigerian populace regardless of their socio-economic status in making provision for guarantees in the form of mortgage insurance to lenders for loans granted to low and middle income 
households with no credit history. There is need for proactive action by the government to provide affordable land and housing in order to reverse the trend urbanisation are causing in meeting the housing needs of different socioeconomic households.

\section{Provision of Primary Infrastructures}

The government at all level should be encouraged to take it as part of their responsibilities to make provision for primary infrastructures. Consumers consider location on their housing consumption based on their financial capability, value and taste. The provision of infrastructures should be done in such a way to adequately attract and stimulate private sectors' interest in housing development.

\section{Conclusion}

Right to adequate and affordable housing is an important component of standard of living. Improvement in housing stock when it is well planned with acceptable standard of infrastructures and affordable cost, it becomes strategically important social and economic investment to the individual family and the community at large. Five determining factors were extracted through exploratory factor analysis on 21 variables out of 45 variables developed from literature review. The factors formed the basis for appraising housing affordability. Three of the determining factors are confirmed to be significant in explaining the housing affordability with the aid of the multiple regression results. These include land price, housing satisfaction and house rent. The suggestion on housing affordability strategies has been made for adoption. This is to enhance effective strategies for housing affordability and to improve living condition of the consumers of different socio-economic status. The findings could help both the private and public housing sector in gaining better insight and understanding on determining factors for housing affordability in Ibadan urban centres.

As housing contributes towards improved health and increase productivity, government should see to the situation where every individual lives in decent and affordable housing. This research and findings are limited to Ibadan urban centre. The author is of opinion that it can be replicated in other urban centres within Nigeria as well as other developing countries to authenticate the applicability and reliability of the determining factors confirmed in this study.

\section{References}

Ademiluyi, I.A. (2010). Public Housing Delivery Strategies in Nigeria: A Historical Perspective of Policies and Programmes. Journal of Sustainable Development in Africa, 12(6): 153-161.

Akinyode, B.F. (2014). Students' Satisfaction and Perception on Rented Apartments in Nigeria: Experiment of lautech Students. International Journal of Business and Social Research, 4(7): 58-70.

Arimah, B.C. (1997). The Determinants of Housing Tenure Choice in Ibadan, Nigeria. Urban Studies, 34(1): 105-124. doi:10.1080/0042098976294

Arku, G., Luginaah, I. and Mkandawire, P. (2012). "You Either Pay More Advance Rent or You Move Out": Landlords/Ladies' and Tenants' 
Dilemmas in the Low-income Housing Market in Accra, Ghana. Urban Studies, 49(14): 3177-3193. doi:10.1177/0042098012437748

Bramley, G. (2011). Affordability, poverty and housing need: triangulating measures and standards. Journal of Housing and the Built Environment, 27(2): 133151. doi:10.1007/s10901-011-92554

Chen, M.-C., Tsai, I.-C. and Chang, C.O. (2007). House prices and household income: Do they move apart? Evidence from Taiwan. Habitat International, 31: 243-256. doi:10.1016/j.habitatint.2007.02.00 5

CIH. (1992). Rents and Levels, Rent Structure and Affordability: The Chartered Institute of Housing - A Guide for Local Authorities and Housing Associations. Retrieved from

https://scholar.google.com/scholar? $\mathrm{q}=$ Urban+Residential+Housing + an d+Low-

Income+Earners $\% 3 \mathrm{~A}+\mathrm{A}+\mathrm{Study}+$ of + Makurdi+Metropolis\%2C+Benue + State $\% 2 \mathrm{C}+$ Nigeria\&btnG $=\& \mathrm{hl}=\mathrm{en}$ \&as_sdt $=0 \% 2 \mathrm{C} 5$

Clark, W., Deurloo, M. and Dieleman, F. (2006). Residential mobility and neighbourhood outcomes. Housing Studies, 21(3): 323-342.

Collen, H., and Hoekstra, J. (2001). Values as determinants of preferences for housing attributes. Journal of Housing and the Built Environment, 16(3-4): 285-306.

Coolen, H., Boelhouwer, P. and van Driel, K. (2002). Values and goals as determinants of intended tenure choice. Journal of Housing and the Built Environment, 17(3): 215-236.

Ellen, I.G., Horn, K.M. and O'Regan, K. M. (2013). Why Do Higher-income Households Choose Low-income Neighbourhoods? Pioneering or Thrift? Urban Studies, 50(12): 24782495. doi:10.1177/0042098012474511

Field, A. (2009). Discovering Statistics Using SPSS (Third ed.). London: SAGE Publications Ltd.

Gough, K.V., and Yankson, P. (2011). A Neglected Aspect of the Housing Market: The Caretakers of Periurban Accra, Ghana. Urban Studies, 48(4): 793-810. doi:10.1177/0042098010367861

Hair, J.F., Black, W.C., Babin, B.J. and Anderson, R.E. (2010). Multivariate Data Analysis: Overview of Multivariate Methods (Seventh Edition ed.). Pearson Prentice Hall: Upper Saddle River, New Jersey: Pearson Education International.

Ibem, E.O. and Amole, D. (2013). Subjective life satisfaction in public housing in urban areas of Ogun State, Nigeria. Cities, 35: 51-61. doi:10.1016/j.cities.2013.06.004

Jack, E. F. (2008). Response Rates and Responsiveness for Surveys, Standards, and the Journal. American Journal of Pharmacetical Education, 72(2-Article 43): 1-3.

Kauko, T. (2007). An analysis of housing location attributes in the inner city of Budapest, Hungary, using expert judgements. International Journal of Strategic Property Management, 11(4), 209-225.

Kotchen, M.J. and Reiling, S.D. (2000). Environmental attitudes, motivations, and contingent 
valuation of nonuse values: a case study involving endangered species. Ecological Economics, 32(1): 93107.

Lee, N.J. and Ong, S.E. (2005). Upward mobility, house price volatility, and housing equity. Journal of Housing Economics, 14(2): 127-146. doi:10.1016/j.jhe.2005.06.004

Meen, G. (2002). The Time-Series Behavior of House Prices: A Transatlantic Divide? Journal of Housing Economics, 11(1): 1-23. doi:10.1006/jhec.2001.0307

Mitchell, R.C. and Carson, R.T. (1989). Using surveys to value public goods: the contingent valuation method: Resources for the Future.

Newton, P. and Meyer, D. (2010). The Determinants of Urban Resource Consumption. Environment and Behavior, 44(1): 107-135. doi:10.1177/0013916510390494

Nubi, O.T. (2008). Affordable housing delivery in Nigeria. Paper presented at the The South African foundation International Conference and Exhibition, Cape Town.

Olatubara, C.O. (2007). Fundamentals of Housing. In (eds.), , pp. In T. Agbola, L. Egunjobi, and C.O. Olatubara (Eds.), Housing Development and Management: A Book of Readings (pp. 70-106). Nigeria.: Department of Urban and Regional Planning, Faculty of Social Science, University of Ibadan.

Onu, V. and Onu, A.J.C. (2012). Urban Residential Housing and Low-Income Earners: A Study of Makurdi Metropolis, Benue State, Nigeria. European Scientific Journal, 8(28): 231-246.

Shanmugapriya, S. and Subramanian, K. (2013). Investigation of Significant Factors Influencing Time and Cost
Overruns in Indian Construction Projects. International Journal of Emerging Technology and Advanced Engineering, 3(10): $734-740$.

Sinai, T. and Souleles, N.S. (2003). Owneroccupied housing as a hedge against rent risk. Retrieved from http://www.nber.org/papers/w9462

Snively, S. (2009). What is housing (consumption good, investment good, asset class, industry, infrastructure), and, what role does it play as an automatic stabilizer. Paper presented at the Workshop on After the Boom Where to From Here, Reserve Bank of New Zealand.

Tan, T.-H. (2012). Meeting first-time buyers' housing needs and preferences in greater Kuala Lumpur. Cities, 29(6): 389-396. doi:10.1016/j.cities.2011.11.016

Tsai, I.-C. and Pen, C.-W. (2011). Bubbles in the Taiwan housing market: The determinants and effects. Habitat International, 35: 379-390. doi:10.1016/j.habitatint.2010.11.010

Wang, D. and Li, S.-M. (2006). Socioeconomic differentials and stated housing preferences in Guangzhou, China. Habitat International, 30(2): 305-326.

doi:10.1016/j.habitatint.2004.02.009

Wattage, P., Smith, A., Pitts, C., McDonald, A. and Kay, D. (2000). Integrating environmental impact, contingent valuation and cost-benefit analysis: empirical evidence for an alternative perspective. Impact Assessment and Project Appraisal, 18(1): 5-14.

Wong, P.S.P. and Cheung, S.O. (2005). Structural Equation Model of Trust and Partnering Success. Journal of Management in Engineering, 21: 70$80 . \quad$ doi:10.1061//asce/0742$597 x / 2005 / 21: 2 / 70$ 